Dmitry O. Sergeev ${ }^{1 *}$, Nikolai N. Romanovskiy ${ }^{2}$, Gennadiy S. Tipenko ${ }^{3}$, Sergey N. Buldovich $^{4}$, Anatoly V. Gavrilov ${ }^{5}$, Kenji Yoshikawa ${ }^{6}$, Vladimir E. Romanovsky ${ }^{7}$

${ }^{1}$ Permafrost Laboratory, Institute of Environmental Geoscience, Russian Academy of Sciences; Tel: 7495 6074789; e-mail: d.sergeev@geoenv.ru

* Corresponding author

${ }^{2}$ Geocryology Department, Faculty of Geology, Moscow State University;

Tel: 7 4959391937, Fax: 74959328889

${ }^{3}$ Geocryology Laboratory, Institute of Environmental Geoscience, Russian Academy of Sciences; Tel: 7495 6074789, e-mail: gstipenko@mail.ru

${ }^{4}$ Geocryology Department, Faculty of Geology, Moscow State University;

Tel: 7495 9394920, e-mail: ser_bul@rambler.ru

${ }^{5}$ Laboratory of the Geological Environment, Faculty of Geology, Moscow State University; Tel: 7495 9394920, e-mail: agavrilov37@mail.ru

${ }^{6}$ Water Resource Center, University of Alaska Fairbanks, USA

${ }^{7}$ Geophysical Institute, University of Alaska Fairbanks; PO Box 750109, Fairbanks, AK 99775, USA; Tel: 1907 4747459, fax: 1907 4747290;

e-mail: veromanovsky@alaska.edu

\title{
THE INFLUENCE OF CHANGING CLIMATE AND GEOCRYOLOGICAL CONDITIONS ON THE REGIME OF REGIONAL DISCHARGE AND ICING IN THE UPPER PART OF LENA RIVER'S BASIN
}

\begin{abstract}
Using the balance method authors showed for the case of 1990 that the reaction of the river discharge on the climate change is different in the regions with continuous and sporadic permafrost extent. In mountain with continuous permafrost extent the climate warming has no strong influence on the river discharge but affects on the ice-mounds' volume. In case of sporadic permafrost extent the decreasing of permafrost area to $30 \%$ leads to decreasing of snow-melting overflow up to $38 \%$. Also the period of the flood became longer because the underground storage increasing that takes away the precipitation, snow-melting and condensation water from surface discharge.
\end{abstract}

KEY WORDS: permafrost, underground water, river run-off, climate change, numerical simulation.
INTRODUTION

The climatic and hydrologic regimes of Arctic and Subarctic rivers are strongly impacted by the permafrost distribution within their watersheds. Rivers that collect their waters entirely from watersheds with continuous permafrost distribution (i.e. permafrost is everywhere, drastically limiting the influence of groundwater in the water balance), such as the Kuparuk and Colville Rivers in Alaska or the Yana and Indigirka Rivers in East Siberia, practically cease their discharge into the Arctic Ocean during the winter. In contrast, the larger arctic rivers, which extend their watersheds into the regions with discontinuous permafrost or even into the permafrostfree areas (Ob', Yenisei, Lena, Mackenzie), continue to discharge a significant amount of water into the Arctic Ocean during the entire winter. Moreover, the ratio of "winter" to "summer" discharge decrease among 
the Great Siberian Rivers (Ob', Yenisei, Lena) accordingly to the extend of permafrost in their watersheds [Savelieva et al., 2001].

Based on this observation, it becomes obvious that the seasonality in the arctic river discharge can change significantly with a warmer climate. The predicted warming in this century will be significant enough to start the permafrost degradation in many areas in the Northern Hemisphere [Anisimov et al., 2001; Sazonova et al., 2001]. Degradation of permafrost will significantly change the permafrost spatial extent and can affect its vertical thickness. As a result, conditions of groundwater recharge, flow, discharge and storage will be altered considerably, increasing the role of subsurface flow in the water balance. Altogether, it will change the seasonality of the arctic river discharge into the Arctic Ocean, increasing winter flow, it will probably increase the total discharge as well. We already see the changes. With practically no increase in precipitation over the Siberian river watersheds [Savelieva et al., 2000 and 2001], there was observed a slight increase in these rivers total discharge during the last three decades and, most importantly, this increase is much more noticeable during the winter months [Savelieva et al., 2000 and 2001]. During winter, all other sources of river discharge but groundwater accumulated in unfrozen zones within permafrost (taliks) are locked in temporary storage as snow or ice. Taking into account the observed increase in permafrost temperatures in Siberia over the same period of time [Pavlov, 1994; Romanovsky et al., 2001a and $2001 \mathrm{~b}]$, the most reasonable explanation of changes in the winter river discharge is the permafrost dynamics within the Siberian river watersheds and especially in the upper parts of their basins where permafrost is the warmest and already discontinuous.

An increase in thickness of the active layer (the layer of soil above the permafrost that experiences thawing every summer) alone cannot explain the observed increase in the winter discharge. Though the active layer dynamics can explain changes in stream recessions in the Arctic and Subarctic [Dingman, 1973; McNamara et al., 1998], the effect of increased active layer thickness on winter river discharge is minimal. Even within discontinuous permafrost the active layer freeze-up is usually complete by the end of January. In the continuous permafrost zone the complete freeze-up occurs in late October - November [Romanovsky and Osterkamp, 1995 and 2000; Osterkamp and Romanovsky, 1997]. As numerous data from the permafrost research in Siberia show, long before this time, about two to three weeks after onset of the freezing, the excess groundwater in the active layer on slopes drains away completely [Romanovskiy, 1983]. The active layer within the flat surfaces in uplands, river terraces, and floodplains continues to hold a significant amount of groundwater until its complete freeze-up. However, this water does not contribute significantly to the streamflow and freezes in the active layer with some small local redistribution. Any natural increase in the base flow of the arctic rivers in the late winter and early spring (before snowmelt started) should be related to changes in subsurface flow and storage volume in the talik zones within the permafrost.

The most dramatic changes in subsurface flow occur when permafrost starts to thaw from its surface and the active layer fails to freeze back completely (in this case a talik will be formed over the permafrost) [Kane, 1997]. However, significant changes in subsurface storage and flow could happen even without widespread permafrost degradation. Relatively small increases in the size of the inter-permafrost taliks, which are usually related to the fractured tectonics zones [Romanovsky and Afanasenko, 1980; Romanovsky and Romanovskiy, 1984] or to the layers of coarse-grained sediments with increased hydraulic conductivity, will lead to significant changes in subsurface flow and storage with subsequent changes in river discharge, especially in its seasonality. These changes will be the most noticeable in the uplands and mountain regions in the upper parts of the northern rivers where all thermal 
subsurface processes are coupled very tightly with subsurface water movements (subsurface hydrology or hydrogeology) and where the permafrost is the most dynamic.

It is obvious from the previous discussion that some very important processes are already happening in the "Hydrology-HydrogeologyPermafrost" system in Siberia, resulting in unexplained increases in the Siberian river discharge (especially its winter component). In an attempt to properly describe the arctic river discharge into the Arctic Ocean (especially its seasonality), the Regional and Pan-Arctic Hydrological models have to take into account changes in subsurface storage, fluxes, and changes in partitioning of water movement between surface (or near-surface) and deeper subsurface flow. In other words, these models have to include the permafrost-hydrogeological conditions and changes in these conditions that will occur as a result of climate warming and permafrost degradation.

The overall goal of the proposed research is to obtain a deeper understanding of coupled thermal and hydrogeological processes of heat and water exchange within different permafrost zones along the Lena River and to use this understanding for prediction of changes in arctic river discharge into the Arctic Ocean as a result of climate warming and permafrost degradation.

This investigation will be based on analysis, synthesis, and integration of the existing data on the Lena River hydrology and available permafrost dynamics data within the Lena River basin. In addition, extensive field studies will be conducted to quantify changes in hydrological and permafrost regimes during the last 100 years. Remote sensing studies will be applied to detect geomorphological changes that may be attributed to degradation of permafrost (thermokarst) or changes in ground water dynamics (icing formation and extent). Intensive use of physically based two- and three-dimensional coupled permafrosthydrogeological numerical models for sensitivity analysis and for predictions of permafrost-hydrogeological system dynamics will be the key methods employed to achieve this goal. Field research, including application of geophysical methods, will be also performed to obtain specific permafrosthydrogeological information for the specific sites. This information will be used as input data for our numerical modeling. Image analyses will provide key input parameters for model initiation and verification.

To accomplish this goal there are four possible perspective objectives to meet:

1. Developing the physically based numerical models of ground water recharge/discharge, and subsurface flow and storage in the permafrost affected hydrostratigraphic units at typical locations within the principal parts of Lena River basin.

2. Estimate the two- and three-dimensional permafrost dynamics within these units as a response to climate change during the $21^{\text {st }}$ century.

3. Assess the effect of these changes in permafrost characteristics on the hydrology and hydrogeology within the Lena River basin and as a result on the Lena River discharge patterns.

4. Assess and quantify the impact of these changes across Siberia and throughout the Arctic.

\section{RELIEF, GEOLOGICAL AND PERMAFROST CONDITIONS}

The areas of investigation are located at the upper part of Lena Basin on the Chulman River (the tributary of Aldan River with the area $3840 \mathrm{~km}^{2}$ ) and Chara River (the tributary of Olyokma River with the area $4150 \mathrm{~km}^{2}$ ). The head water of Chulman River is located in the Stanovoy Ridge and the middle part of the stream cross the middle part of Mesozoic Chulman Depression. This territory is well studied by hydrogeologists and permafrost scientists. 
The permafrost here is discontinuous [Fotiev, 1965; Southern Yakutia, 1975, pp. 291-311]. The Chulman Depression as tectonic region has a plateau relief with the typical heights above sea level from $150 \mathrm{~m}$ (valleys) to $950 \mathrm{~m}$ (watershed divides). The watershed divides are wide and have the flat shape. The slopes are steep (10-20\%). The permafrost exists on the lower part of the slopes and on the bottoms of valleys. The flat watershed divide are the area of infiltration of atmospheric precipitation. In winter the deep seasonal cooling of the rocks takes place here (up to $5 \mathrm{~m}$ depth).

Chara River has the sources in Kodar and Udokan Ridges with ancient crystalline rocks. Kodar Ridge has the alpine relief with up to $2999 \mathrm{~m}$ altitude and living glaciation. Udokan Ridge has the smooth bald mountain relief with up to $2174 \mathrm{~m}$ altitude. The upper part of Chara Basin is located in Chara Rift Depression that has the $40 \mathrm{~km}$ width. Here the permafrost is continuous.

\section{METEOROLOGICAL AND HYDROLOGICAL CONDITIONS}

The comparison of long term tendencies of meteo- and hydrological characteristics showed the difference between Chara's and Chulman's basins. In Chulman we saw the opposite trends of the air temperature and precipitation in one hand and the river discharge in the other hand (see Fig. 2a). It's noticeable the synchronism of precipitation's and river discharge's anomalies in several periods (1950-58, 1967-70, 1982-90, or 19 years from 45) and abrupt anomalies' lack of coincidence in the other periods.

In Chara Basin we did not saw the evident trends of precipitation and river discharge despite the similar air temperature warming (see Fig. 2b). The synchronism of anomalies here existed during longer period of time (1957-59, 1963-69, 1972-75, 1979-95, or 25 years from 38$)$.

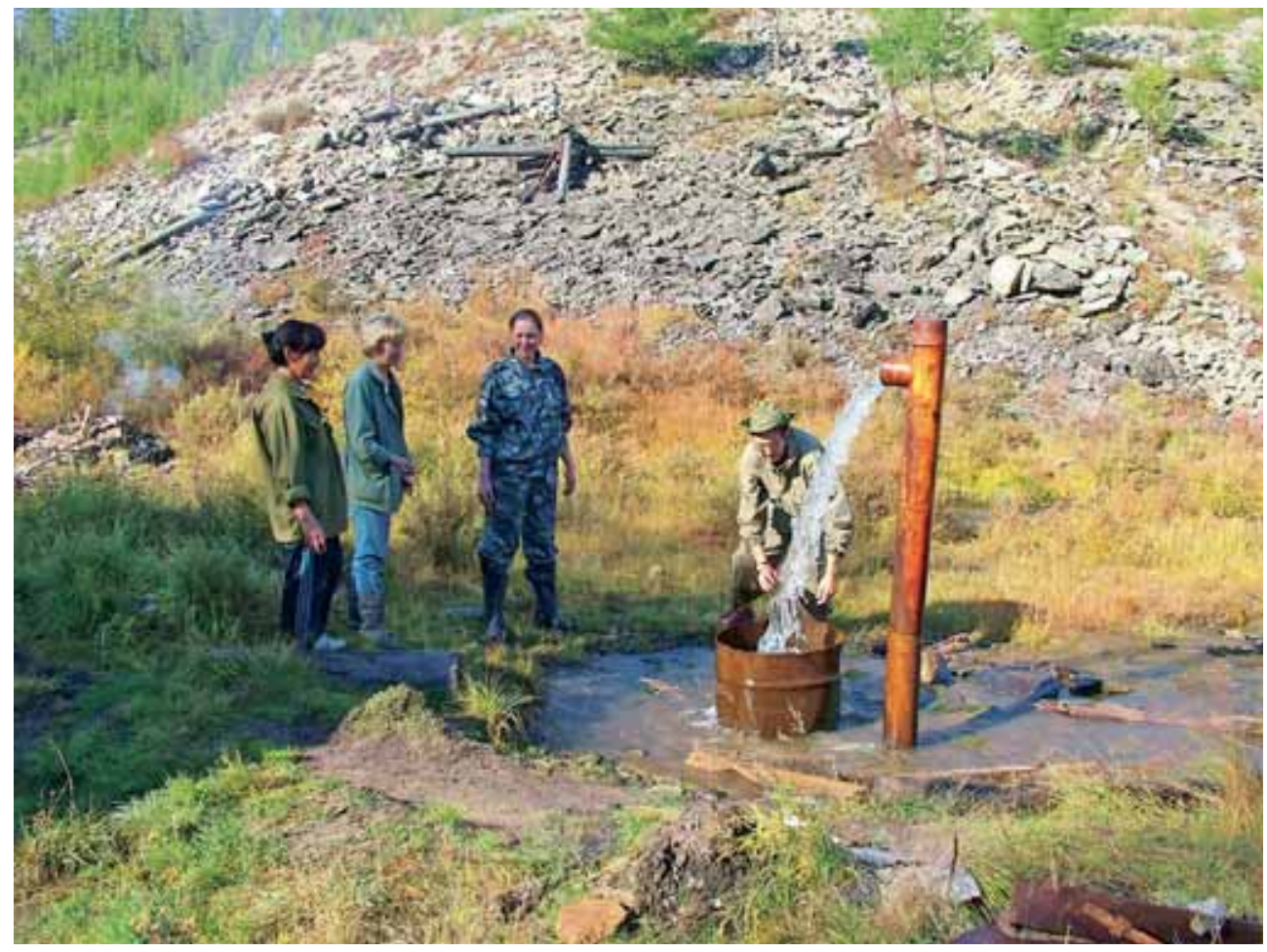

Fig. 1. The discharge of open talik pressure water in the valley bottom (Southern Yakutia). This head water forms the icing $\mathrm{n}$ the winter 


\section{METHODS AND ASSUMPTIONS}

Authors formed hypothesis that the major ground of the ambiguous river discharge's response to precipitation trend is the underground water dynamics linked with permafrost condition [Vsevolojskiy, Kurinova, 1989]. To estimate the role of permafrost change in the river discharge variation the method of balances was used. We took into account in the balance equation the water amount from melting snow, icing and glacier, the liquid precipitations, the evaporation, regional underground discharge, condensation in the active layer.

Chulman Basin was divided on two parts: plateau (40\% of area) and high mountain (60\% of area). In 1976 Permafrost Department of Moscow State University drew-up the permafrost map of this region with the scale $1: 200000$.

This map helped us calculate the ratio of permafrost and taliks areas. In seventies on the plateaus the permafrost was located at $69 \%$ of the territory. In the southern part of Chulman Basin the permafrost occupied $97 \%$ of the territory.

Climatic data was obtained from Chulman meteorological station. In the Stanovoy Ridge the amount of precipitation is more up to 1.5 times than in Chulman depression was assumed (no direct data about it).

The magnitude of precipitation did not take in account. Authors assumed that the precipitation water was going without any delay from permafrost areas to the rivers' channels.

However in the plateau surface without permafrost the precipitation water was going to underground space using the zone of high fissuring (tectonic or cryogenic) and was reaching the river bed in the next month that was following the month of precipitation. This assumption was supported by the hydrogeological observations of head water level and discharge dynamics (Fig. 1).
We supposed that all underground water was discharging in the river within each subdivision of the basin, in other words the underground water in Stanovoy Ridge was discharging in rivers within Stanovoy Ridge. Snowfalls was starting in October, 10\% of snow was melting in April, consequently $70 \%$ - in May, and 20\% - in June. Also we supposed that the water from snow melting was flowing as the water from liquid precipitations.

\section{RESULTS AND DISCUSSION}

Reconstructed water balance for each month of 1990 was reflected in calculation annual hydrographs (Fig. 2). In Chulman the calculated and real hydrograph showed the noticeable trace difference. That was concerned the time of spring tide and the existing of the second peak of discharging in September (Fig. 2a). We expected that the dynamics of river discharge should be corresponded to precipitation regime but in 1990 it was not show up.

Authors explain this phenomenon by the large underground collectors that adsorb the surplus of atmospheric water. In Chara this difference was not be showed though the amount of the spring tide was be overrated as well as the August's peak and September's discharge was be unappreciated (Fig. 2b). This fact corresponds to continuous permafrost extent in Northern Transbaykalia and low importance of underground discharge in this region.

The maximum of monthly discharge showed the gradual decreasing in long-term aspect (Fig. 3). The regional evaporation in both regions did not show the significant change in the 50-year period. Only in the early seventies this parameter slightly decreased that was compensated later [Berezovskaya et al., 2005].

The change of permafrost extent brings to change the river discharge regime. In Chulman region this link is significant because 

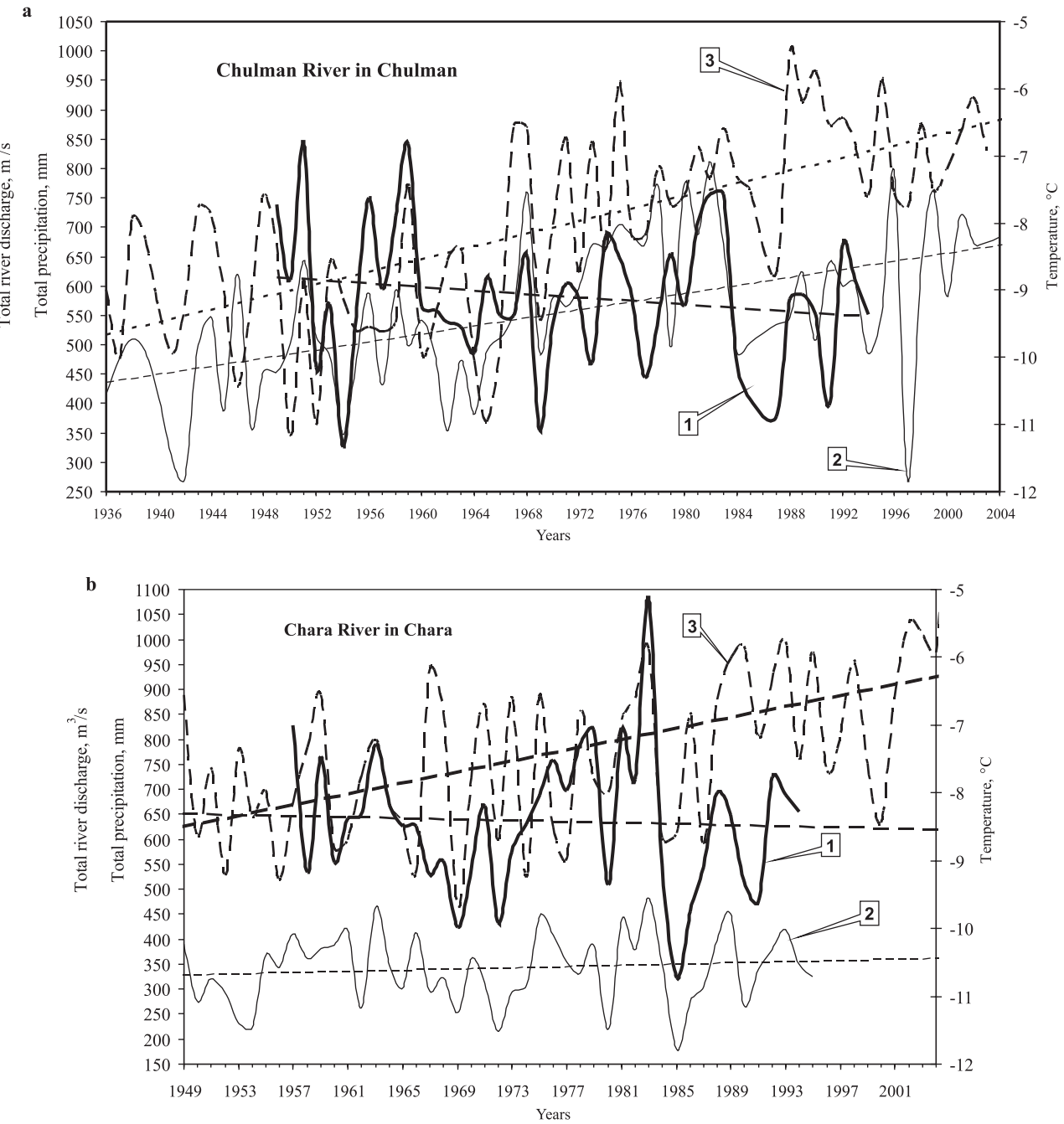

Fig. 2. The dynamics of mean annual values of climate and river discharge characteristics in Chulman (a) and Chara (b):

1 - river discharge (left scale), 2 - precipitation (left scale), 3 - air temperature (right scale)

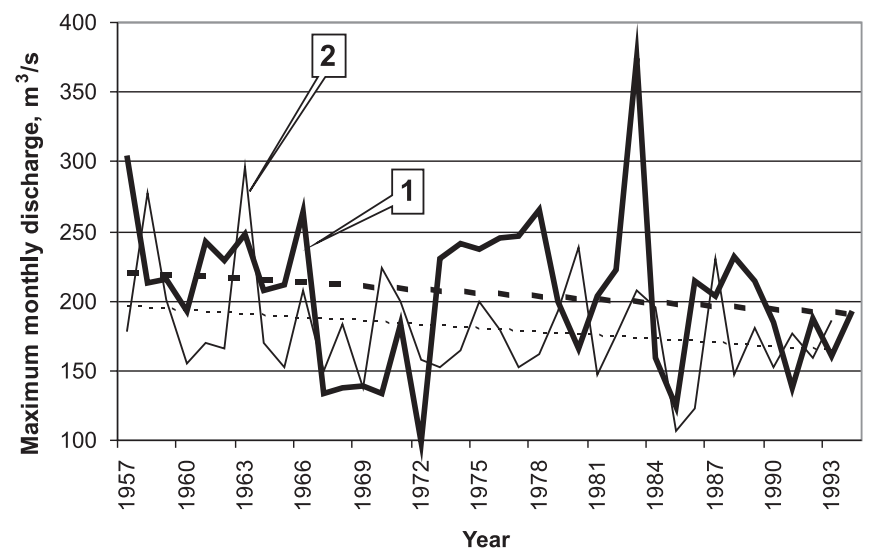

Fig. 3. The dynamics of maximum monthly discharge in Chara (1) and Chulman (2). The dashed lines show the corresponding linear trends 
the dependency of water sink areas from permafrost distribution change. In Chara the climate change bring to permafrost temperature shift only because the low regional level of ground temperature (up to $-7 \div-9^{\circ} \mathrm{C}$ ). In Chulman Region the increasing of talik underground water feeding zones up to $10 \%$ brings to decreasing of the peak of river flooding up to $15 \%$. The consecutive increasing of the first one brings to shrinking of spring tide up to $38 \%$ and to prolongation of the flooding to the end of June. The summer-end peak decreased and extended also but did not disappeared completely. These changes were linked with the water flow splitting when the part of atmospheric precipitation goes to underground taliks through watershed divide. If the permafrost extent will increase then the discharge delay will increase too.

a

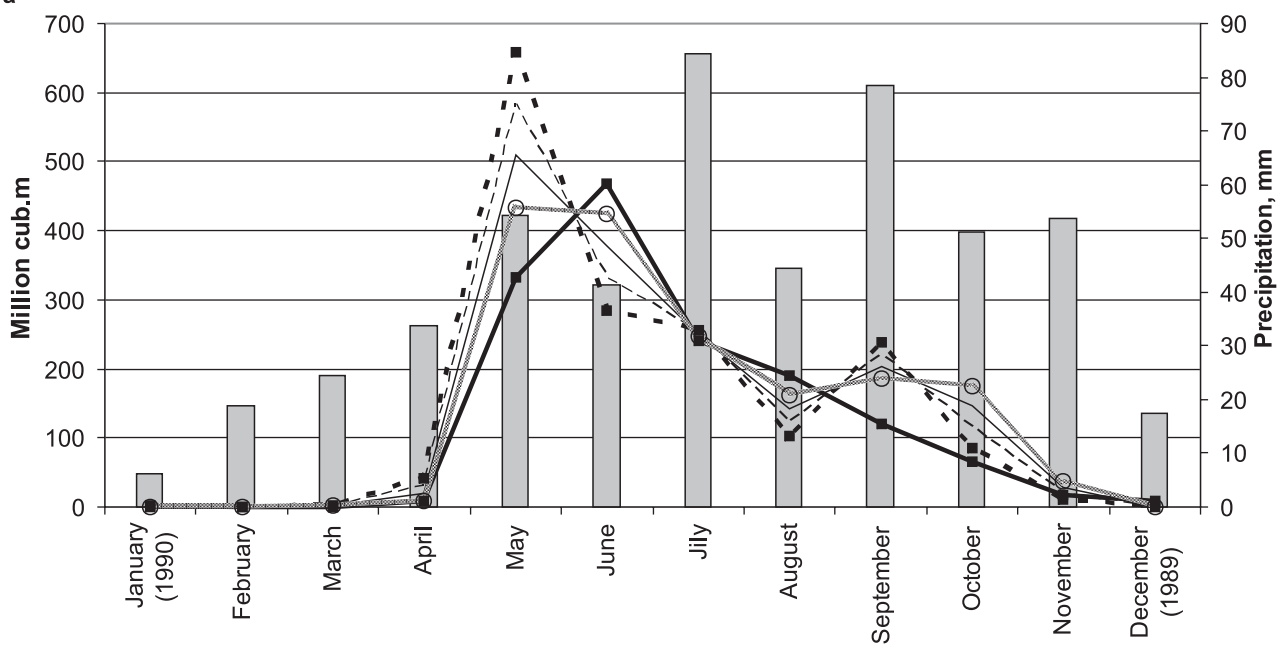

b

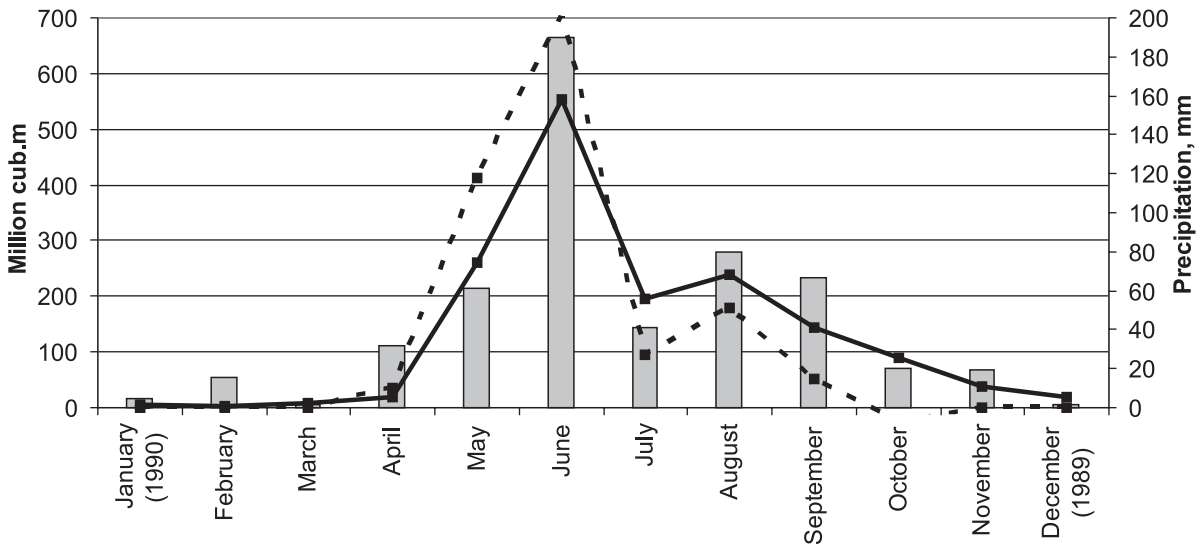

$\square 1 \rightarrow-2-3-34-5 \div 6$

Fig. 4. The comparison of real and calculated river discharge for 1990 in Chulman (a) and Chara (b): 1 - Liquid precipitation equivalent (bar chart, the right scale), 2 - Real river discharge in the river bed (left scale), 3 - Calculated river discharge (left scale), 4 - Calculated river discharge with the talik areas increased up to 10\% (left scale), 5 -Calculated river discharge with the talik areas increased up to 20\% (left scale), 6 -Calculated river discharge with the talik areas increased up to $30 \%$ (left scale) 
It is noticeable that the permafrost extent estimation was obtained from old permafrost map (1976). We have no precise data about actual permafrost distribution. So the underestimation of taliks' areas canned be the cause of the discrepancy between observed and calculated hydrographs of Chulman River. Thus the climate warming bring to enlargement of underground water feeding zones and to increasing of hydrogeological collectors'volume.

In Northern type of cryolithozone (e.g. NorthernTransbaykalia, Chara) the permafrost temperatures are low and the volume of talik collectors is less than permafrost massifs' volume. In this case the climate warming influences on local springs' flow-rate, on the volume of underbed river taliks and therefore on the intensity of ice mound formation. The volume of ice mounds in Chara Region was strongly decreased the last 20 years [Shesternyov, Verkhoturov, 2006].

In Southern type of cryolithozone the climate warming influences on the regime of river discharge and bring to softening of river hydrograph shape (Fig. 4a). This phenomenon is linked with the increasing of part of atmospheric water that flow from watershed areas under surface and under permafrost massifs with monthly delay.

\section{CONCLUSION}

Using the balance method authors showed for the case of 1990 that the reaction of the river discharge on the climate change is different in the regions with continuous and sporadic permafrost extent. In mountain in case of continuous permafrost extent the climate warming has no strong influence on the river discharge but affects on the ice-mounds' volume. In case of sporadic permafrost extent the decreasing of permafrost area to 30\% leads to decreasing of snow-melting overflow up to $38 \%$. Also the period of the flood became longer because the underground storage increasing that takes away the precipitation, snow-melting and condensation water from superficial discharge.

Practical importance of fulfilled study is evident for the more accurate prediction of hydrological regime of Siberian rivers.

\section{ACKNOWLEDGEMENT}

This work was completed grace a support of NASA "Current Climate Change over Eastern Siberia and their Impact on Permafrost Landscape, Ecosystem Dynamics, and Hydrological Regime", as well as support of Russian Fund of Basic Research grant 06-05-64959a "The influence of the climate change and geocryological conditions on the regime of regional discharge and icing regime at typical mountain catchments'areas in Lena River's basin". Authors also appreciate S.L.Berezovskaya and M.V.Kasimskaya for the effective helping with data processing and interpretation.

\section{REFERENCES}

1. Anisimov, O., et al. (2001) Polar Regions (Arctic and Antarctic). In "Climate Change: Impacts, Adaption and Vulnerability, the Contribution of Working Group II of the Intergovernmental Panel on Climate Change, Third Assessment Review». Cambridge University Press, pp. 801-841.

2. Berezovskaya S., Yang D., Hinzman L. (2005) Long-term annual water balance analysis of the Lena River // Global and Planetary Change, 48, pp. 84-95.

3. Dingman, S.L. (1973) Effects of permafrost on stream characteristics in the discontinuous permafrost zone of central Alaska. In Permafrost, the North American Contribution to 
the Second International Conference, Yakutsk, U.S.S.R., July 16-28, 1973, Proceedings: Washington, D.C., National Academy of Sciences, p. 447-453.

4. Fotiev S.M. (1965) Underground Water and Permafrost of Southern Yakutian Coal Basin. Moscow, Nauka, 231 pp. (in Russian).

5. Kane, D.L. (1997) The Impact of Hydrologic Perturbations on Arctic Ecosystems Induced by Climate Change. In: Oechel, W.C., Callaghan, T., Gilmanov, T., Holten, J..., Maxwell, B., Molau, U. and B. Sveinbjornsson (eds.), Global Change and Arctic Terrestrial Ecosystem, Springer Verlag, New York, pp. 63-81.

6. McNamara J.P., Kane D.L. and L.D. Hinzman (1998) An analysis of streamflow hydrology in the Kuparuk River Basin, Arctic Alaska: a nested watershed approach, Journal of Hydrology, 206: 39-57.

7. Osterkamp, T.E., and V.E. Romanovsky (1997) Freezing of the active layer on the Coastal Plain of the Alaskan Arctic, Permafrost and Periglacial Processes, 8 (1), 23-44.

8. Pavlov, A.V. (1994) Current changes of climate and permafrost in the Arctic and Sub-Arctic of Russia, Permafrost and Periglacial Processes, 5: 101-110.

9. Romanovskiy, N.N. (1983) Underground Waters in Cryolitozone. Moscow State University Press, 232 pp. (in Russian).

10. Romanovsky, V.E. and V.E. Afanasenko (1980) New Data About Permafrost-Hydrogeological Structure of the Dzhagdi-Socktahan Range. In: Geocryological Conditions of the BAMRegion, Yakutsk (in Russian).

11. Romanovsky, V.E., and T.E. Osterkamp (2000) Effects of unfrozen water on heat and mass transport processes in the active layer and permafrost, Permafrost and Periglacial Processes, 11, 219-239.

12. Romanovsky, V.E., and T.E. Osterkamp (1995) Interannual variations of the thermal regime of the active layer and near surface permafrost in Northern Alaska. Permafrost and Periglacial Processes, 6, pp. 313-335.

13. Romanovsky, V.E., Osterkamp, T.E., Sazonova, T.S., Shender, N.I. and V.T. Balobaev (2001a) Permafrost Temperature Dynamics Along the East Siberian Transect and an Alaskan Transect, Tohoku Geophysical Journal (Sci. Rep. Tohoku Univ., Ser. 5), Vol. 36, No. 2, pp. 224-229.

14. Romanovsky, V.E., Shender, N.I., Sazonova, T.S., Balobaev, V.T., Tipenko, G.S. and Rusakov, V.G. (2001 b) Permafrost Temperatures in Alaska and East Siberia: Past, Present and Future. In: Proceedings of the Second Russian Conference on Geocryology (Permafrost Science), Moscow, June 6-8, pp. 301-314.

15. Romanovsky, V.E. and N.N. Romanovskii (1984) The Improvement of Electrical Conductivity Method Efficiency for the Purposes of the Small Scale Engineering and GeocryologicalHydrogeological Surveys, Ingenernaja Geologia, 4: 116-125 (in Russian).

16. Savelieva, N.I., Semiletov, I.P., Vasilevskaya, L.N. and S.P. Pugach (2000) A climate shift in seasonal values of meteorological and hydrological parameters for northeastern Asia, Progress in Oceanography, 47: 279-297.

17. Savelieva, N.I., Semiletov, I.P., Weller, G. and L.N. Vasilevskaya (2001) Empirical evidence for North Asia climate shift in the early 1970s. In I.P. Semiletov (ed.), Changes in the AtmosphereLand-Sea System in the Amerasian Arctic, Dalnauka, Vladivostok, pp. 41-54.

18. Sazonova, T.S., Romanovsky, V.E., Sergeev, D.O. and Tipenko, G.S. (2001) The Modeling of Active Layer Thickness and Permafrost Temperature Regime (past, present and future) 
within East-Siberian Transect, using GIS, EOS, Trans. AGU, 82 (47), Fall Meet. Suppl., Abstract, F180.

19. Shesterniov D.M., Verkhoturov A.G. (2006) Icing of Transbaykalia Region. Chita, Chita State University Press, 213 pp. (in Russian).

20. Southern Yakutia (1975) Ed. by Kudryavtzev V.A., Moscow, MSU Publishing, 444 pp. (in Russian).

21. Vsevolojskiy V., Kurinova T. (1989) Water Balance of Intensive Water Migration Zone in Southern Part of Cryolithozone. In: Geocryological and Hydrological Investigations of the Intensive Water Migration Zone. Moscow, Nauka, pp. 13-23 (in Russian).

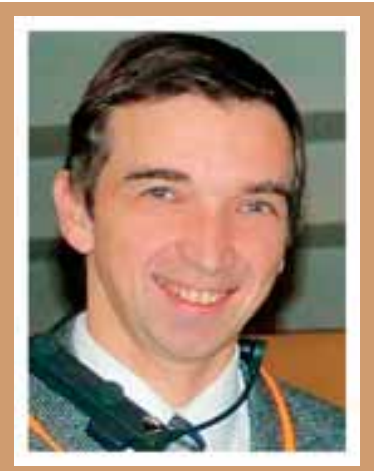

Dmitry O. Sergeev graduated from Moscow State University in 1986 as geologist-hydrogeologist and obtained his PhD degree in 1991 ("Kurums of Bald Mountain Belt in Northern Tranbaikalia region"). He is the Chief of Permafrost Laboratory at the RAS Institute of Environmental Geoscience. He participates in national and international research on permafrost dynamics due the climate change and anthropogenic impact. D.Sergeev participated in expedition to Northern Transbaykal region and Southern Yakutia (1982-1990, 2005-2011), Central, Western and Northern Alaska (2001-2003), and Norilsk region (1991-1992). $\mathrm{He}$ is the member of the International Permafrost Association and the International Association on Engineering Geology.

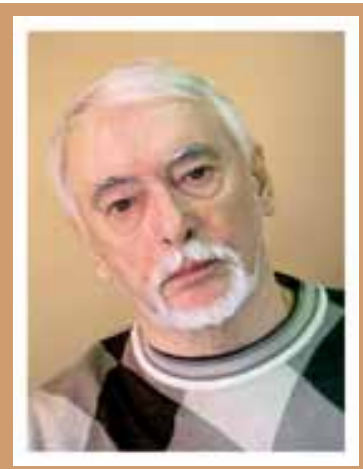

Nicolai N. Romanovsky is Doctor of Science and Emeritus Professor at Geological Faculty of the Moscow State University. His research is mainly in regional and historical geocryology, Quaternary geology, geocryological processes and phenomena, hydrogeology of cryolithozone and environmental protection in cold regions. He was the leader of fundamental investigations of polygonal phenomena in permafrost zone, interaction between surface and underground water in cold regions, evolution of offshore permafrost and gaz-hydrate zone in relation to climate and sea level change. More than 300 papers, 15 books and manuals summarize the results of his work.

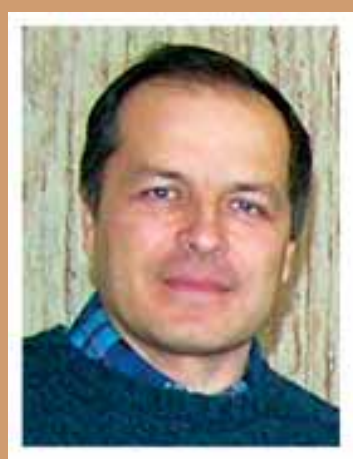

Gennadiy S. Tipenko received his MSc. in Mathematics and Ph. D. in Mathematics from the Moscow State University in Russia. He had several research and teaching positions at the Moscow State University and at the University of Alaska Fairbanks He is currently leading researcher of the Geocryology Laboratory, Institute of Environmental Geoscience (IEG RAS). His research interests include the computational mathematics and mathematical modeling of environmental and engineering problems involving ice and permafrost (in the areas of soil physics, thermodynamics, heat transfer with phase transitions, groundwater movement, gas hydrates, sub sea permafrost, thermokarst and seasonal snow cover). He is the author of 40 journal publications and numerous reports. 

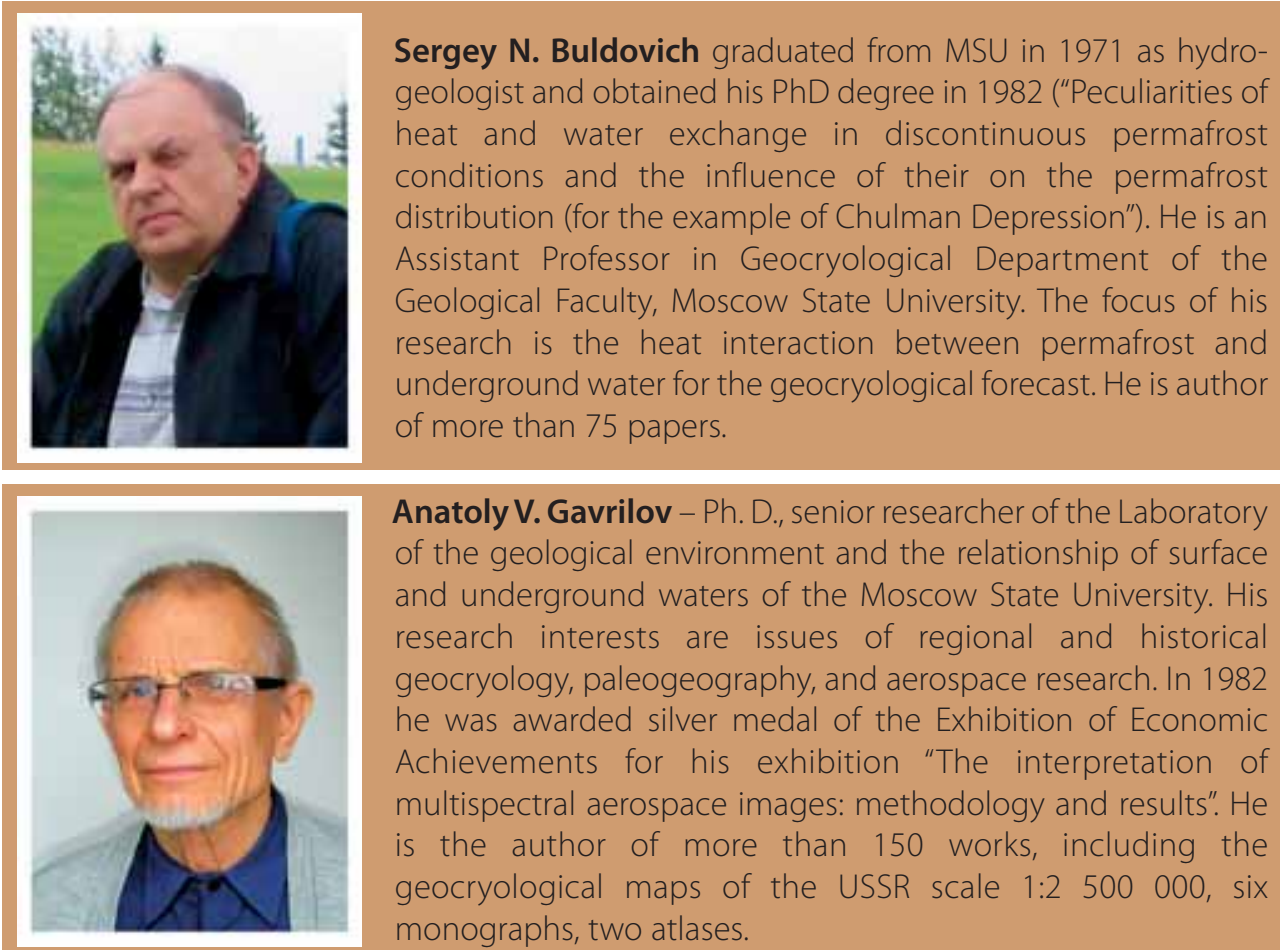

Anatoly V. Gavrilov - Ph. D., senior researcher of the Laboratory of the geological environment and the relationship of surface and underground waters of the Moscow State University. His research interests are issues of regional and historical geocryology, paleogeography, and aerospace research. In 1982 he was awarded silver medal of the Exhibition of Economic Achievements for his exhibition "The interpretation of multispectral aerospace images: methodology and results". He is the author of more than 150 works, including the geocryological maps of the USSR scale 1:2 500 000, six monographs, two atlases.

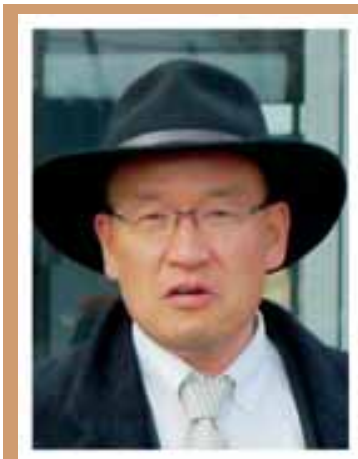

Kenji Yoshikawa, a research professor, works at the University of Alaska Fairbanks, USA. His areas of research are permafrost geomorphology, groundwaterhydrology, and extraterrestrial (Martian) permafrost, but pingos and icings are his primary interest. Yoshikawa's research locations have included Svalbard, West Greenland, Alaska, Siberia, Tibet, Canadian Arctic, and Mongolia, where he has located many pingos and examined their internal structures and hydrology. He organized and took part in many field investigations, including searching the permafrost at Mount Kilimanjaro, Mexico or Peruvian Andes. He has published more than 50 peer-reviewed papers as the first author or coauthor during the recent years. He also has made contributions to books and academic conferences, and is invited to give keynote lectures at several universities and institutes.

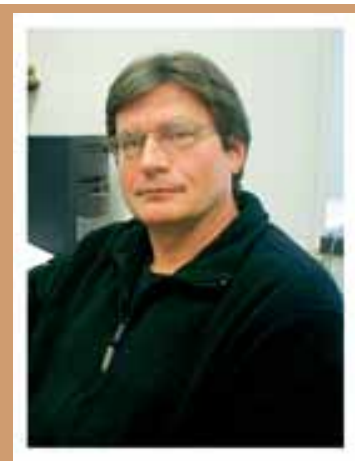

Vladimir E. Romanovsky is a Professor in Geophysics at the Geophysical Institute and the Department of Geology and Geophysics, University of Alaska Fairbanks. He also heads the Geophysical Institute Permafrost Laboratory. His work involves internationally coordinated research on permafrost temperature changes in Alaska, Russia, Canada, Greenland, Kazakhstan, and Mongolia. He is also involved in numerical modeling of past, present and future permafrost dynamics and the remote sensing of permafrost and periglacial processes. His research interests include the scientific and practical aspects of environmental and engineering problems involving ice and permafrost. He is the author of $130+$ refereed journal publications, many reports, and book chapters. He was a co-author of ACIA 2005 for Chapter 6 "Cryosphere and Hydrology" and the lead author of the Chapter 7 "Frozen Ground" in UNEP 2007 Global Outlook for lce and Snow and the Chapter on Permafrost in SWIPA. 